\title{
Evaluation of Some Serum Antioxidants in Mandibular Bone Defect Healing in Rabbits Orally Supplemented with Pomegranate Peel Extract
}

\author{
Sarchil Ezadeen Mohyadeen (MSc) ${ }^{1}$, Rezan Majeed Omer(PhD) ${ }^{2}$ and Bakhtiar \\ Muhialdin Ahmed(PhD) ${ }^{3}$
}

\author{
${ }^{1}$ College of Dentistry, Hawler Medical University, Erbil, Iraq \\ ${ }^{2}$ College of Dentistry, Hawler Medical University, Erbil, Iraq \\ ${ }^{3}$ College of Dentistry, Hawler Medical University, Erbil, Iraq \\ Correspondence Address: \\ Rezan Majeed Omer \\ ${ }^{1}$ College of Dentistry, Hawler Medical University, Erbil, Iraq \\ email: rezanomer400@gmail.com
}

Received: 27 April 2021

Revised: 20 May 2021

Accepted: 10 June 2021

Published: 25 October 2021

Diyala Medical Journal 2021:21(1): 86-97

\section{Abstract}

Background: Pomegranate ( $\mathrm{PG}$ ) fruit (punicagranatum L, Punicaceae contains many bioactive substances that play important role in the treatment of a variety of medical problems. Among PG parts, it was observed that the peel had the most potent antioxidant activity.

Objective: To evaluate some serum antioxidants levels in mandibular bone injury healing in rabbits orally supplemented with pomegranate peel extract (PPE).

Patients and Methods: Forty-five male rabbits (1-1.2 kg) were used and they were divided into 3 groups; the baseline group consisted of 5 rabbits without creating mandibular bone defects. 20 rabbits were used as a study group with creating mandibular bone defects and they received orally $1 \mathrm{ml} /$ day of PPE. Another 20 rabbits were used as a control group with creating mandibular bone defects without receiving PPE. For each rabbit of both study and control groups, a circular defect of $3 \mathrm{~mm}$ in diameter was made in the mid labial area of the alveolar bone of the lower right central incisor. Blood samples were taken from the baseline

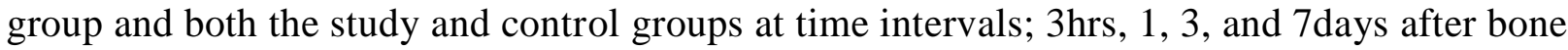
defect creation, for estimation of serum albumin (Alb), bilirubin (Bili), zinc ( $\mathrm{Zn}$ ), and magnesium $(\mathrm{Mg})$ levels.

Results: Serum Bili levels significantly increased 1and 3 days after bone defect creation in both study and control groups, while the levels returned back to baseline in a study group, 7 days after the operation. Serum $\mathrm{Alb}, \mathrm{Zn}$, and Mg levels showed a significant decrease in study and 
control groups, 1 day and 3 days after the operation, while the levels of these parameters returned back to baseline, in a study group, 7 days after bone defect.

Conclusion: Supplementation of PPE can affect serum antioxidants and this was accompanied by the increase in the bone healing rate process.

Keywords: Pomegranate peel, mandibular bone defect, albumin, bilirubin, divalent cations, antioxidant

\section{Introduction}

Pomegranate (PG) was found to have antioxidant, anti-inflammatory, and antibacterial activities [1-4]. It was observed that the PG biological activity is mainly due to its antioxidant potency coming from anthocyanins and tannins [5,6]. Almost 26\%$30 \%$ of $\mathrm{PG}$ fruit is the peel which has the highest anti-oxidant activity due to its content of a large number of polyphenols such as flavonoids, hydrolysable tannins and punicalagin $[8,9]$.

The PG peel was used as a treatment for many medical cases, such as osteoporosis, which is a chronic disease which is related to bone remodeling disturbance resulted in progressive bone loss due to the presence of oxidation stress in the osteoporosis pathogenesis[10]. Spilmont et al, investigated that whether the consumption of PPE could limit the process of osteopenia[11]. PPE was formulated as a topical gel and was examined for its wound healing property against skin excision wounds. The topical application of this PPE formulated resulted in significant improvement in the wound model[12]. The skin extract of PG was studied for its wound healing potency in the rat excision wound model, it was found that PG promotes significant wound healing in rats[13].

Bone is continuously remodeled by the roles of both osteoblasts and osteoclasts[14]. Disturbance in bone remodeling may be caused by an increase in resorption activity over the bone-formation rate or by low bone turnover [15]. It was found that polyphenolic compounds can affect osteoporosis[16,17], inhibit osteoclast differentiation18 and stimulate osteoblast formation[19].

This study was designed to evaluate some serum antioxidants (albumin, bilirubin, Zn and $\mathrm{Mg}$ ) in mandibular bone wound healing in rabbits orally supplemented with PPE.

\section{Patients and Methods}

\section{Animals}

This study was performed in Hawler Medical University, College of Medicine, animal house and College of Dentistry, Department of basic sciences. The work was carried out on 45 healthy male rabbits (aged 8-10 months, and weighing 1-1.2 Kg), they were divided into three groups; a baseline group consisting of 5 rabbits without mandibular bone defect creation. The study group consisting of 20 animals ( 5 rabbits for each time interval) orally received $1 \mathrm{ml} /$ day ethanolic PPE, starting from seven days before surgically created a mandibular bone defect, and continuing till 7 days after the mandibular bone defect operation, according to wound healing model. The third group; the control group consisted of 20 animals (5 rabbits for each time interval), they received $1 \mathrm{ml} / \mathrm{kg}$ of distilled water instead of PPE. All 
the animals were fed with commercial food pellets and given water according to standard care rules.

\section{Mandibular bone defect operation}

Rat IL-1B ELISA kit for estimation of serum interleukin-1beta (IL-1 $\beta$ ), KOMA BIOTECH INC.USA Aloe Vera's mature, safe and fresh $98 \%$ (gel) Chlorhexidine 2\% (Periocare) gel (Kin company-Spanish).

\section{Animals, Experimental studies and sampling}

This part was performed by a specialized dentist. After anesthetizing the animals with $(40 \mathrm{mg} / \mathrm{kg})$ ketamine and $(4 \mathrm{mg} / \mathrm{kg})$ xylazin [20], and by using a \# 15 Bard-Parker scalpel blade, a $2 \mathrm{~cm}$ in length sulcular incision was extended along the distolabial surface of the lower right central incisor to the distolabial surface of the lower left central incisor. In the mid-labial area of the alveolar bone of the lower right central incisor, a circular defect of $3 \mathrm{~mm}$ in diameter was made after fullthickness flap reflection[21], $2 \mathrm{ml}$ of normal saline was used to irrigate the area. To close the wound and replaced in the previous position, the incision was sutured by one stitch with (4/0) black silk; the suture was removed after 7 days without using antimicrobial agents.

\section{Preparation of Pomegranate Peel Extract}

Rafraf method was used to prepare PPE[22]. $500 \mathrm{~g}$ of Punica peel from the fresh fruits was obtained and dried in an oven at 40 ${ }^{\circ} \mathrm{C}$. The particles were powdered finely by a grinder and filtrated to remove the remnants, then extracted in $80 \%$ ethanol-water by maceration method. Using Whatman filter paper No.42, the extract was filtered two times. The filtrate was dried at $50{ }^{\circ} \mathrm{C}$, then $100 \mathrm{mg}$ of dry powdered Punic peel was suspended in $1 \mathrm{ml}$ of distilled water,.Finally, this suspension was administrated to the animals in the study group.

$1 \mathrm{ml}$ of $50 \mathrm{mg} / \mathrm{kg} /$ day of the PPE suspension was orally supplemented to the rabbits of the study group. This supplementation started 7 days before the surgical operation, and continued until 7 days after the operation (according to the wound healing model)[23], while the control group orally received $1 \mathrm{ml}$ distilled water /day instead of PPE suspension.

\section{Blood collection}

Under subcutaneous general anesthesia and through cardiocentesis, $5 \mathrm{ml}$ blood was collected from each rabbit [20] of the baseline group and both study and control group at time intervals; $3 \mathrm{~h}, 1,3$, and 7 days after the operation. The blood samples were centrifuged for $5 \mathrm{~min}$ at 3000rpm, then the serum was separated and stored at $-20{ }^{\circ} \mathrm{C}$ until chemical analysis, which included; determination of serum Alb[24], Bili[25] , $\mathrm{Zn}[26]$ and $\mathrm{Mg}$ [27] levels. These parameters were calorimetrically determined using specific kits.

\section{Statistical analysis}

The statistical package for the social science (SPSS, Statistical for Windows, version 20.0 Armonk, NY: IBM Corp) was used for data analysis. The data of this study was described by the mean with the standard deviation $\pm(\mathrm{SD})$. A paired sample $\mathrm{t}$ - test was used for comparing two means. The difference in the mean value scores with $\mathrm{p}$ value $<0.001$ for serum Bili, Alb and $\mathrm{Mg}$ and $\mathrm{p}$-value $<0.05$ for serum $\mathrm{Zn}$ are statistically significant. 


\section{Results}

Table (1) shows the levels of serum Alb, Bili, $\mathrm{Zn}$, and $\mathrm{Mg}$ in rabbits receiving $\mathrm{PPE}$ (study group) before and after surgically created mandibular bone defect. The results indicate a significant decrease in serum Alb, $\mathrm{Zn}$, and $\mathrm{Mg}$ levels, one day $(2.84 \pm 0.32$, $82.55 \pm 4.82$, and0.857 \pm 0.121 respectively) and three days $(3.07 \pm 0.36,80.34 \pm 4.56$, and $0.876 \pm 0.145$ respectively) after surgically created mandibular bone defect in comparison to baseline values. While 7 days after mandibular bone defect creating, the serum levels of all these parameters raised nearly to their baseline values. The results showed that there was a significant increase in serum Bili levels in rabbits receiving PPE, three hours and one day after a surgically created mandibular bone defect in comparison to the baseline value. While the Bili levels will retune back nearly to its baseline value, by $7^{\text {th }}$ day after mandibular bone defect creation.

Table (1): Comparison of the mean concentration \pm SD of serum albumin, bilirubin, zinc and magnesium levels (each time interval after creating surgical bone) in a study group to baseline data

\begin{tabular}{|c|c|c|c|c|c|}
\hline Parameters & Groups & $\begin{array}{l}\text { No. of } \\
\text { Rabbits }\end{array}$ & Mean & $\begin{array}{l}\text { Std. Deviation } \\
\quad( \pm \text { SD })\end{array}$ & P-Value \\
\hline \multirow{5}{*}{$\begin{array}{l}\text { Serum } \\
\text { Albumin } \\
(\mathrm{g} / \mathrm{dl})\end{array}$} & Baseline & 5 & 3.78 & 0.32 & \\
\hline & $3 \mathrm{H}$ & $\overline{5}$ & 3.64 & 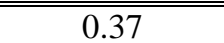 & NS \\
\hline & $1 \mathrm{D}$ & 5 & 2.84 & 0.32 & $\mathrm{~S}$ \\
\hline & $3 \mathrm{D}$ & $\overline{5}$ & 3.07 & 0.36 & $\mathrm{~S}$ \\
\hline & $7 \mathrm{D}$ & 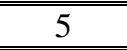 & 3.75 & 0.37 & NS \\
\hline \multirow{5}{*}{$\begin{array}{l}\text { Serum } \\
\text { Bilirubin } \\
(\mathrm{mg} / \mathrm{dl})\end{array}$} & Baseline & $\overline{5}$ & 0.411 & 0.040 & \\
\hline & $3 \mathrm{H}$ & 5 & 0.462 & 0.033 & $\bar{S}$ \\
\hline & $1 \mathrm{D}$ & $\overline{5}$ & 0.473 & 0.034 & $\mathrm{~S}$ \\
\hline & $3 \mathrm{D}$ & 5 & 0.431 & 0.038 & NS \\
\hline & $7 \mathrm{D}$ & $\overline{5}$ & 0.417 & 0.032 & NS \\
\hline \multirow{5}{*}{$\begin{array}{l}\text { Serum Zinc } \\
\quad(\mathrm{ug} / \mathrm{dl})\end{array}$} & Baseline & 5 & 103.63 & 5.22 & \\
\hline & $3 \mathrm{H}$ & 5 & 100.35 & 5.76 & NS \\
\hline & $1 \mathrm{D}$ & 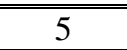 & 82.55 & 4.82 & $\mathrm{~S}$ \\
\hline & $3 \mathrm{D}$ & $\overline{5}$ & 80.34 & 4.56 & $\bar{S}$ \\
\hline & $7 \mathrm{D}$ & 5 & 102.85 & 6.11 & NS \\
\hline \multirow{5}{*}{$\begin{array}{c}\text { Serum } \\
\text { Magnesium } \\
(\mathrm{mg} / \mathrm{l})\end{array}$} & Baseline & $\overline{5}$ & 3.31 & 0.33 & \\
\hline & $3 \mathrm{H}$ & 5 & 3.05 & 0.34 & NS \\
\hline & 1D & 5 & 2.34 & 0.36 & $\mathrm{~S}$ \\
\hline & $3 \mathrm{D}$ & 5 & 2.61 & 0.34 & $\mathrm{~S}$ \\
\hline & $7 \mathrm{D}$ & $\overline{5}$ & 3.29 & 0.31 & NS \\
\hline
\end{tabular}

*H: Hour, D: Day, S: Significance, NS: Non-Significance

Table (2) shows the levels of serum Alb, Bili, $\mathrm{Zn}$, and $\mathrm{Mg}$ in rabbits receiving distilled water (control group), before and after time intervals of creating a mandibular bone defect. Serum Alb, Zn, and Mg levels showed a significant decrease throughout all time intervals after bone defect creation in comparison to baseline values. The results also showed that serum Bili level significantly increased at all time intervals after creating a bone defect. 
Table (2): Comparison of mean concentration $\pm \mathrm{SD}$ of serum albumin, ilirubin, zinc and magnesium levels (each time interval after creating surgical bone) in control group to baseline data

\begin{tabular}{|c|c|c|c|c|c|}
\hline Parameters & Groups & $\begin{array}{l}\text { No. of } \\
\text { Rabbits }\end{array}$ & Mean & $\begin{array}{l}\text { Std. Deviation } \\
( \pm \mathrm{SD})\end{array}$ & P-Value \\
\hline \multirow{5}{*}{$\begin{array}{l}\text { Serum } \\
\text { Albumin } \\
\qquad(\mathrm{g} / \mathrm{dl})\end{array}$} & Baseline & 5 & 3.78 & 0.40 & \\
\hline & $3 \mathrm{HH}$ & $\bar{~} 5$ & 3.58 & 0.35 & NS \\
\hline & 1D & $\overline{5}$ & 2.75 & 0.31 & $\bar{S}$ \\
\hline & $3 \mathrm{D}$ & $\overline{5}$ & 2.93 & 0.37 & $\bar{S}$ \\
\hline & $7 \mathrm{D}$ & $\overline{5}$ & 3.16 & 0.32 & $\bar{S}$ \\
\hline \multirow{5}{*}{$\begin{array}{l}\text { Serum } \\
\text { Bilirubin } \\
(\mathrm{mg} / \mathrm{dl})\end{array}$} & Baseline & 5 & 0.411 & 0.037 & \\
\hline & $3 \mathrm{H}$ & $\overline{5}$ & 0.473 & 0.035 & $\mathrm{~S}$ \\
\hline & 1D & $\overline{5}$ & 0.461 & 0.035 & $\overline{\mathrm{S}}$ \\
\hline & 3D & 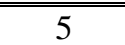 & 0.452 & 0.032 & $\overline{\mathrm{S}}$ \\
\hline & $7 \mathrm{D}$ & $\overline{5}$ & 0.445 & 0.030 & $\overline{\mathrm{S}}$ \\
\hline \multirow{5}{*}{$\begin{array}{l}\text { Serum Zinc } \\
(\mu \mathrm{g} / \mathrm{dl})\end{array}$} & Baseline & 5 & 103.63 & 5.22 & \\
\hline & $3 \mathrm{H}$ & 5 & 103.17 & 5.36 & $\mathrm{NS}$ \\
\hline & $1 \mathrm{D}$ & 5 & 83.32 & 5.02 & $\mathrm{~S}$ \\
\hline & $3 \mathrm{D}$ & 5 & 78.77 & 4.88 & $\mathrm{~S}$ \\
\hline & $7 \mathrm{D}$ & 5 & 86.47 & 5.95 & $\mathrm{~S}$ \\
\hline \multirow{5}{*}{$\begin{array}{l}\text { Serum } \\
\text { Magnesium } \\
(\mathrm{mg} / \mathrm{dl})\end{array}$} & Baseline & 5 & 3.31 & 0.33 & \\
\hline & $3 \mathrm{H}$ & 5 & 2.94 & 0.38 & NS \\
\hline & $1 \mathrm{D}$ & 5 & 2.23 & 0.34 & $\mathrm{~S}$ \\
\hline & $3 \mathrm{D}$ & 5 & 2.39 & 0.37 & $\mathrm{~S}$ \\
\hline & $7 \mathrm{D}$ & $\overline{5}$ & 2.52 & 0.33 & S \\
\hline
\end{tabular}

*H: Hour, D: Day, S: Significance, NS: Non-Significance

Table (3) shows the comparison of mean \pm SD value between the study group and control group with time intervals after creating a surgical bone defect in mandibular anterior teeth (it was assessed by using Paired sample t-test). Significant differences in all the parameters levels were found between the study group and control group, only after 7days after bone defect creation, while non-significant differences in the parameters at all the other time intervals were observed.

Table (3): Inter group comparison between mean $\pm \mathrm{SD}$ values of study group and control group regarding serum albumin, bilirubin, zinc, and magnesium levels in rabbits with each time interval after creating surgical bone defect in mandibular anterior teeth

\begin{tabular}{|c||c||c|c|c|}
\hline \multirow{4}{*}{ Parameters } & $\begin{array}{c}\text { Time interval } \\
\text { Hour (H) } \\
\text { Day (D) }\end{array}$ & $\begin{array}{c}\text { Study group } \\
(\text { mean } \pm \text { SD) }\end{array}$ & $\begin{array}{c}\text { Control group } \\
(\text { mean } \pm \text { SD) }\end{array}$ & P-value \\
\hline \hline \multirow{3}{*}{$\begin{array}{c}\text { Serum } \\
\text { Albumin } \\
(\mathrm{g} / \mathrm{dl})\end{array}$} & 3H & $3.64 \pm 0.37$ & $3.58 \pm 0.35$ & $\mathrm{NS}$ \\
\cline { 2 - 5 } & 1D & $2.84 \pm 0.32$ & $2.75 \pm 0.31$ & $\mathrm{NS}$ \\
\cline { 2 - 5 } & 3D & $3.07 \pm 0.36$ & $2.93 \pm 0.37$ & $\mathrm{NS}$ \\
\hline \hline \multirow{3}{*}{$\begin{array}{c}\text { Serum } \\
\text { Bilirubin } \\
(\mathrm{mg} / \mathrm{dl})\end{array}$} & 7D & $3.75 \pm 0.37$ & $3.16 \pm 0.32$ & $\mathrm{~S}$ \\
\cline { 2 - 5 } & 3H & $0.462 \pm 0.033$ & $0.473 \pm 0.035$ & $\mathrm{NS}$ \\
\cline { 2 - 5 } & 3D & $0.473 \pm 0,034$ & $0.461 \pm 0.035$ & $\mathrm{NS}$ \\
\hline \hline
\end{tabular}




\begin{tabular}{|c|c|c|c|c|}
\hline \multirow{4}{*}{$\begin{array}{l}\text { Serum } \\
\text { Zinc } \\
(\mu \mathrm{g} / \mathrm{dl})\end{array}$} & $3 \mathrm{H}$ & $100.35 \pm 5.76$ & $103.17 \pm 5.36$ & NS \\
\hline & $\overline{1 D}$ & $82.55 \pm 4.82$ & $83.32 \pm 5.02$ & NS \\
\hline & $3 \mathrm{D}$ & $80.34 \pm 4.56$ & $78.77 \pm 4.88$ & $\overline{\mathrm{NS}}$ \\
\hline & $\overline{7 D}$ & $102.85 \pm 6.11$ & $86.47 \pm 5.95$ & $\overline{\mathrm{S}}$ \\
\hline \multirow{4}{*}{$\begin{array}{c}\text { Serum } \\
\text { Magnesium } \\
(\mathrm{mg} / \mathrm{dl})\end{array}$} & $3 \mathrm{H}$ & $3.05 \pm 034$ & $2.94 \pm 0.38$ & $\mathrm{NS}$ \\
\hline & $1 \mathrm{D}$ & $2.34 \pm 0.36$ & $2.23 \pm 0.34$ & NS \\
\hline & $3 \mathrm{D}$ & $2.61 \pm 034$ & $2.39 \pm 0.37$ & NS \\
\hline & $7 \mathrm{D}$ & $3.29 \pm 0.31$ & $2.52 \pm 0.33$ & $\mathrm{~S}$ \\
\hline
\end{tabular}

* S: Significance, NS: Non-Significance

\section{Discussion}

Throughout The physiological role of antioxidants is to prevent damage to cellular components by free radicals[28]. Antioxidants are two types; small organic molecules and large molecules[29].

The results of this study indicated that serum Alb, Zn, and Mg levels decreased after surgically created mandibular bone defect, however daily oral administration of pomegranate peel extract can modulate these parameters levels, seven days after bone defect creating, while in distilled water administration group, the levels were still low, thus mandibular bone defect creating process resulted in a decrease in some serum antioxidants variables (such as albumin) and some metal ions (such as $\mathrm{Zn}$ and $\mathrm{Mg}$ ) that have a vital role in immune and in controlling oxidative stress systems[30], while PPE has potency to increase these important serum antioxidants thereby speeding up the rate of bone healing process.

The features of the wound healing process that can be observed in injured tissues are epithelialization, antioxidant effects, and some biochemical characterizations [12]. It was published that, PPE can regulate the differentiation of bone cells, leading to an improvement in resorption to formation ratio, anti-inflammatory effects, and anti-oxidative potency in the bone microenvironment[31]. Oral administration of aqueous PPE extract to rats resulted in the healing of wound models [32]. The study of Shishehbor et al, 2016 showed that supplementation of pomegranate juice seems to improve some inflammatory markers and to increase plasma antioxidants status in type 2 diabetes[33]. The findings of Amri et al., 2017, showed the neuroprotective effects of PG extracts, and they explained the mechanisms throughout stimulating of some serum antioxidants [34]. Al-Olayan et al, 2014, studied the effects of $\mathrm{PG}$ consumption on some serum markers of oxidative stress. Their results showed that PG juice caused a significant elevation in serum antioxidants and a significant reduction in lipid peroxidation and nitric oxide [35].

It was found that the most important explanation of the positive effects of albumin, its antioxidant potency [36,37]. The antioxidant properties of albumin are associated with its structure. This is due to its content of multiple ligand-binding capacities for trapping free radicals $[38,39]$. Another explanation for the antioxidant properties of albumin was its ability to bind bilirubin, 
lipids and homocysteine. The serum albuminbilirubin complex can inhibit lipid peroxidation $[39,40]$.

Serum albumin can regulate the cellular Glutathione (GSH) level, thus protecting cells from oxidative stress [41]. The Cys34 residue in albumin acts as a free radical scavenger, thus it has the ability for trapping reactive oxygen species (ROS) and reactive nitrogen species (RNS)[42].

In the present study, serum bilirubin increased after surgically created mandibular bone defect, however daily oral administration of PPE could modulate this parameter level, seven days after bone defect creating, while in distilled water administration group, the levels were still high.

Bilirubin is a product of hemoglobin degradation, it is known as an endogenous antioxidant. Bilirubin is produced by the reduction of biliverdin, then bilirubin can be oxidized by ROS and return back to biliverdin (a reversible process). In the body, bilirubin is a strong antioxidant and mostly can act against peroxyl radicals[43-45].

$\mathrm{Zn}$ and $\mathrm{Mg}$ are involved in the mechanisms of antioxidant defense[46]. $\mathrm{Zn}$ metal participates in the controlling of chronic inflammatory cases through reducing the inflammatory cytokines. $\mathrm{Zn}$ also takes part in the formation of the antioxidant enzymes, thus reducing the oxidative stress[30]. Marreiro et al, 2017 demonstrated that $\mathrm{Zn}$ took part in the structural integrity of superoxide dismutase (SOD), thus activating SOD which can reduce the toxicity of ROS throughout converting superoxide radicals to hydrogen peroxide and oxygen[47]. $\mathrm{Zn}$ is also a co-factor for many enzymes in the antioxidant defense system [48]. Zn can affect the gene expression of the enzyme glutamate-cysteine ligase; an important enzyme that regulates glutathione de novo synthesis, thus this is another mechanism by which $\mathrm{Zn}$ acts as antioxidant[49].

Studies have found that oxidativeinflammatory stress has been related to hypomagnesemia in Heart Disease patients[50,51]. In obese individuals, $\mathrm{Mg}$ deficiency participates in the developing oxidative stress, as $\mathrm{Mg}$ has a role as an antioxidant, it acts as a cofactor for many enzymes, that maintain cell membrane integrity and stability, thus reducing the effects of oxidative stress[52]. The study of Vida et al, 2020 revealed that $\mathrm{Mg}$ has the main role in regulating immune function and in decreasing oxidative stress[53]. The participation of $\mathrm{Mg}$ in the mechanisms of antioxidant defense is associated with glutathione synthesis[54]. A positive correlation exists between the concentration of $\mathrm{Mg}$ ions and the level of GSH in human blood [54,55]. Two enzymes that are Mg iondependent,catalyze GSH synthesis; these enzymes are gamma-glutamylcysteine synthetase and glutathione synthetase[56]. Shcharbina, 2008, found that $\mathrm{Mg}$ has an antioxidant effect in patients with stroke[57]. The possible mechanism of serum magnesium anti-oxidative action is attributed to its ability to inhibit lipid peroxidation catalyzed by Fe ions, and the supporting of the level of restored glutathione in the cell[58].

\section{Conclusions}

It can be concluded that PPE has the ability to increase the serum antioxidant potency to control the oxidative stress which resulted 
from mandibular bone injury, thus increasing the rate of the healing process.

\section{Recommendations}

Evaluation of serum levels of other antioxidants and antioxidant capacity in the alveolar bone defect in rabbits orally supplemented with pomegranate peel extract, to confirm our results and conclusions.

Source of funding: Nill.

Ethical clearance: The study was approved by the academic ethical committee, college of dentistry, Hawler Medical University.

\section{Conflict of interest: Nill}

\section{References}

[1]Kandylis P, Kokkinomagoulos E. Food Applications and Potential Health Benefits of Pomegranate and its Derivatives. Foods.2020;9(2):122.

https://doi:10.3390/foods9020122.

[2]Aviram M, Volkova N, Coleman R, Dreher M, Reddy MK, Ferreira D, et al Pomegranate phenolics from the peels, arils, and flowers are antiatherogenic. J. Agric. Food Chem. 2008;56 : 1148-1157. https://doi: 10.1021/jf071811q.

[3]Abdollahzadeh S, Mashouf R, Mortazavi H, Moghaddam M, Roozbahani N, Vahedi M. Antibacterial and antifungal activities of Punica granatum peel extracts against oral pathogens. J. Dent. 2011;8: 1-6. https://www.researchgate.net > $\ldots$, Agronomy Punicaceae

[4]Haidari M, Ali M, Ward Casscells S, Madjid M. Pomegranate (punica granatum) purified polyphenol extract inhibits influenza virus and has a synergistic effect with oseltamivir. Phytomedicine. 2009;16: 1127- 1136.https://doi:10.1016/j.phymed.2009.06.0 02.

[5]Haber SL, Joy JK, Largent R. Antioxidant and antiatherogenic effects of pomegranate. Am. J. Health Syst. Pharm. 2011;68: 13021305. https://doi: 10.2146/ajhp100610. [6]Noda Y, Kaneyuki T, Mori A, Packer L. Antioxidant activities of pomegranate fruit extract and its anthocyanidins: Delphinidin, cyanidin, and pelargonidin. J. Agric. Food Chem. 2002; 50: 166-171. https://doi: 10.1021/jf0108765.

[7]Zahin M, Aqil F, Ahmad I. Broad spectrum antimutagenic activity of antioxidant active fraction of Punica granatum L. Peel extracts. Mutat. Res. 2010; 703: 99-107. https://doi: 10.1016/j.mrgentox.2010.08.001.

[8]Tzulker R, Glazer I, Bar-Ilan I, Holland D, Aviram M, Amir R. Antioxidant activity, polyphenol content, and related compounds in different fruit juices and homogenates prepared from 29 different pomegranate accessions. J. Agric. Food Chem. 2007; 55: 9559-9570. https://doi: 10.1021/jf071413n [9]Ismail T, Sestili P, Akhtar S. Pomegranate peel and fruit extracts: A review of potential anti-inflammatory and anti-infective effects. J. Ethnopharmacol. 2012; 143: 397-405. https://doi: 10.1016/j.jep.2012.07.004. [10]Lansky EP, Newman RA. Punica granatum (pomegranate) and its potential for prevention and treatment of inflammation and cancer. J. Ethnopharmacol. 2007;109: 177-206. https://doi: 10.1016/j.jep.2006.09.006.

[11]Spilmont M, Leotoing L, Davicco M-J, Lebecque P, Miot-Noirault E, Pilet P, et al Pomegranate Peel Extract Prevents Bone Loss in a Preclinical Model of Osteoporosis 
and Stimulates Osteoblastic Differentiation in Vitro. Nutrients. 2015; 7(11): 9265-9284. https://doi: 10.3390/nu7115465.

[12]Murthy KN, Reddy VK, Vegas JM, Murthy UD. Study on wound healing activity of Punicagranatum peel. J Med Food. 2004;7: 256-259. https://doi: 10.1089/1096620041224111.

[13]Nayak SB, Rodrigues V, Maharaj S, Bhogadi VS, Wound healing activity of the fruit skin of Punica granatum..J Med Food. 2013;16 (9):857-61. https://doi.org/10.1089/jmf.2012.0229 [14]Rachner T., Khosla S, Hofbauer LC. Osteoporosis: Now and the future. Lancet. 2011;377:1276-1287.https://doi: 10.1016/S0140-6736(10)62349-5

[15]Sandhu SK, Hampson G. The pathogenesis, diagnosis, investigation and management of osteoporosis. J. Clin. Pathol. 2011;64: 1042-1050. . https://doi: 10.1136/jcp.2010.077842.

[16]Scalbert A, Manach C, Morand C, Remesy C, Jimenez L. Dietary polyphenols and the prevention of diseases. Crit. Rev. Food Sci. Nutr. 2005;45:287-306. https://doi: 10.1080/1040869059096.

[17]Hagiwara K, Goto T, Araki M, Miyazaki $\mathrm{H}$, Hagiwara H. Olive polyphenol hydroxytyrosol prevents bone loss. Eur. J. Pharmacol. 2011;662: 78- 84.https://doi: 10.1016/j.ejphar.2011.04.023.

[18]Rassi CM, Lieberherr M, Chaumaz G, Pointillart A, Cournot G. Down-regulation of osteoclast differentiation by daidzein via caspase 3. J. Bone Miner.Res. 2002;17:630638. https://doi: 10.1359/jbmr.2002.17.4.630. [19]Trzeciakiewicz A, Habauzit V, Horcajada MN. When nutrition interacts with osteoblast function: Molecular mechanisms of polyphenols. Nutr. Res. Rev. 2009;22:6881. 10.1017/S095442240926402X.

[20] Hedenqvist, P. 2008. Anaesthesia and analgesia for surgery in rabbits and rats:A comparison of the effects of different compounds. $\mathrm{PhD}$ thesis from the department of physiology and pharmacology, Karolinska institute, Stockholm, Sweden. P12. https://openarchive.ki.se > bitstream > handle , thesis.

21.

[21]Costich ER, Youngblood PJ, Walden JM. A study of the effects of high-speed rotary instruments on bone repair in dogs. Oral Surg. Oral Med. Oral Pathol. 1964 ; 17:563571. https://doi: 10.1016/00304220(64)90359-7

[22]Rafraf M, Hemmati S, Jafarabadi MA, Moghaddam A, Haghighian MK, Pomegranate (Punica Granatum L.) Peel Hydroalcoholic Extract Supplementation Reduces Pain and Improves Clinical Symptoms of Knee Osteoarthritis: A Randomized Double-Blind Placebo Controlled Study. Iran Red Crescent Med J. 2017; 19(1):e38577. https://doi.org/10.1038/s41598-020-78075-x. [23]Bahtiar A, Arifin S, Razalifha A, Qomariah N, Wuyung PE, Arsianti A, Polar Fraction of Punica granatum L. peel extract increased osteoblast number on ovariectomized rat bone. IJHM. 2014; 2 (1): 65-70. http://www.florajournal.com > 2014 > PartA > 11.1.pdf

[24]Doumas BT, Watson WA, and Biggs HG, Albumin standard and the measurement of serum albumin with bromocresol green. Clin.chim.Acta.1971;31:87-96. 
http://doi: 10.1016/0009-8981(71)90365-2. [25]Gambino SR. Bilirubin (modified Jendrassik and Grof). Tn Standard methods in clinical chemistry. Meites S, ed. 5, 55-64. Academic Press: New York. 1965. http://doi:10.1016/B978-1-4831-9686-

2.50012-2

[26]Johnsen O and Eliasson R. Evaluation of a commercially available kit for the colorimetric determination of zinc. Int $\mathrm{J}$ Androl 1987; 10 (2):435-440. http://doi: 10.1111/j.1365-2605.1987.tb00216.x.

[27]Ginder E M, Heath D A. Measurement of magnesium, Clin Chem, 1971;17: 662 https://doi.org/10.11400/kekkaku1923.65.309 [28]Halliwell B, Gutteridge JC. The definition and measurement of antioxidants in biological systems. Free Radic Biol Med 1995;18:125-6. https://doi: 10.1016/08915849(95)91457-3

[29]Young IS, Woodside JV. Antioxidants in health and disease. j Clin. Patho. 2001;54: 176-186.

http://dx.doi.org/10.1136/jcp.54.3.176

[30]Olechnowicz J, Tinkov, A , Skalny A and Suliburska J. Zinc status is associated with inflammation, oxidative stress, lipid, and glucose metabolism. The Journal of Physiological Sciences volume. 2018; 68:1931. https://doi.org/10.1007/s12576-017-05717

[31]Spilmont M, Spilmont M, Léotoing L, Davicco M, Lebecque P, Miot-Noirault E, et al. Pomegranate Peel Extract Prevents Bone Loss in a Preclinical Model of Osteoporosis and Stimulates Osteoblastic Differentiation in Vitro. Nutrients. 2015; 7(11): 9265-9284. https://doi.org/10.3390/nu7115465 [32]Adiga S, Tomar P, Rajput RR. Effect of Punicagranatum peel aqueous extract on normal, and dexamethasone suppressed wound healing in Wister rats. International Journal of Pharmaceutical Sciences Review and Research. 2010; 5: 134140.https://www.researchgate.net/publication /286972742.

[33]Shishehbor F, Shahi M M, Zarei M, Saki Z, Zakerkish M, Shirani F, et al. Effects of Concentrated Pomegranate Juice on Subclinical Inflammation and Cardiometabolic Risk Factors for Type 2 Diabetes: A Quasi-Experimental Study. Int J Endocrinol Metab. 2016; 14(1): e33835. https://doi: 10.5812/ijem.33835.

[34]Amri Z, Ghorbel A, Turki M, AkroutF M, Ayadi F, Elfeki A, Hammami M, Effect of pomegranate extracts on brain antioxidant markers and cholinesterase activity in high fat-high fructose diet induced obesity in rat model. BMC Complement Altern Med, 2017; 17:339. https://doi: 10.1186/s12906-017$1842-9$.

[35]Al-Olayan EM, El-Khadragy MF, AbdelMoneim AE. Protective effects of pomegranate (Punica granatum) juice on testes against carbon tetrachloride intoxication in rats. BMC Complementary Altern Med, 2014;14:164. https://doi: $10.1186 / 1472-6882-14-164$

[36]Quinlan GJ, Margarson MP, Mumby S, Evans TW, Gutteridge JM. Administration of albumin to patients with sepsis syndrome: a possible beneficial role in plasma thiol repletion. Clin Sci (Lond) 1998;95:459-465. https://doi:10.1042/cs0950459

[37]Rostoker G, Griuncelli M, Loridon C, Bourlet T, Illouz E, Benmaadi A. Modulation of oxidative stress and microinflammatory status by colloids in refractory dialytic 
hypotension. BMC Nephrol. 2011;12:58. https://doi: 10.1186/1471-2369-12-58.

[38] Oettl K, Stauber RE. Physiological and pathological changes in the redox state of human serum albumin critically influence its binding properties. $\mathrm{Br} \quad \mathrm{J}$ Pharmacol. 2007;151:580-590. https://doi: 10.1038/sj.bjp.0707251.

[39]Taverna M, Marie A-L, Mira J-P, Guidet B. Specific antioxidant properties of human serum albumin. Ann Intensive Care. 2013;3:4. https://doi: 10.1186/2110-5820-3-4 [40]Neuzil J, Stocker R. Free and albuminbound bilirubin are efficient co-antioxidants for a-tocopherol, inhibiting plasma and low density lipoprotein lipid peroxidation. J Biol Chem.

1994;269:16712-16719. https://doi.org/10.1016/S00219258(19)89449-8.

[41]Cantin AM, Paquette B, Richter M, Larivee P. Albumin-mediated regulation of cellular glutathione and nuclear factor kappa B activation. Am J Respir Crit Care Med. 2000;162:1539-1546. https://doi: 10.1164/ajrccm.162.4.9910106.

[42]Roche M, Rondeau P, Singh NR, Tarnus $\mathrm{E}$, Bourdon E. The antioxidant properties of serum albumin. FEBS Lett. 2008;582:17831787.

https://doi.org/10.1016/j.febslet.2008.04.057 [43]Zelenka J, Dvorák A, Alán L, Zadinová M, Haluzík M, Vítek L. Hyperbilirubinemia protects against aging-associated inflammation and metabolic deterioration. Oxidative Medicine and Cellular Longevity. 2016;2016:1-10.

https://doi.org/10.1155/2016/6190609

[44]Ziberna L, Martelanc M, Franko M, Passamonti S. Bilirubin is an endogenous antioxidant in human vascular endothelial cells. Scientific Reports. 2016;6:29240. https://doi: 10.1038/srep29240.

[45] Hatfield GL, Barclay RC. Bilirubin as an antioxidant: Kinetic studies of the reaction of bilirubin with peroxyl radicals in solution, micelles, and lipid bilayers. Org. Lett. 2004;6:1539-1542.

https://doi.org/10.1021/ol040016k.

[46]Valko M, Morris H, Cronin MT: Metals, toxicity, and oxidative stress. Curr Med Chem 2005;12:1161-1208. https://doi: 10.2174/0929867053764635.

[47]Marreiro D N, Cruz K JC, Morais J B S, Beserra J B, Severo J S, and A R S.Zinc and Oxidative Stress: Current Mechanisms. Antioxidants (Basel) 2017; 6(2): 24.https://doi: 10.3390/antiox6020024. [48]Cruz KJC, Oliveira AR.S. Antioxidant role of zinc in diabetes mellitus. World J. Diabetes. 2015; 6: 333-337.https://doi: 10.4239/wjd.v6.i2.333.

[49]Eide DJ. The oxidative stress of zinc deficiency. Metallomics. 2011; 3: 11241129.https://doi: 10.1039/c1mt00064k.

[50]Ikee R. Cardiovascular disease, mortality, and magnesium in chronic kidney disease: Growing interest in magnesiumrelated interventions. Ren. Replace. Ther. 2018;4:1.https://doi.org/10.1186/s41100-0170142-7.

[51]Munoz-Castaneda JR, Pendon-Ruiz de Mier MV, Rodriguez M, Rodriguez-Ortiz M.E. Magnesium Replacement to Protect Cardiovascular and Kidney Damage? Lack of Prospective Clinical Trials. Int. J.Mol. Sci. 2018; 19 : $664 . \quad$ https://doi: 10.3390/ijms 19030664

[52]Morais JBS , Severo JS , SantosLRD , Melo SR de-S, Santos R de-O, de Oliveira ARS , et al. Role of Magnesium in Oxidative 
Stress in Individuals with Obesity. Biol Trace

Elem Res. 2017;176(1):20-26. https://doi: 10.1007/s12011-016-0793-1.

[53]Vida C , Carracedo J, Sequera P, Bodega $\mathrm{G}$, Perez R, Alique M, et al. Increasing the Magnesium Concentration in various Dialysate Solutions Dierentially Modulates Oxidative Stress in a Human Monocyte Cell Line. Antioxidants 2020; 9: 319.https://doi: 10.3390/antiox9040319.

[54]Barbagallo M, Dominguez LJ, Tagliamonte MR, Resnick LM, Paolisso G. Effects of vitamin $\mathrm{E}$ and glutathione on glucose metabolism: role of magnesium. Hypertension, 1999; 34:1002-1006. https://doi: 10.1161/01.hyp.34.4.1002.

[55]Regan RF, Guo Y. Magnesium deprivation decreases cellular reduced glutathione and causes oxidative neuronal death in murine cortical cultures. Brain Res.2001; 890:177-183. https://doi: 10.1016/s0006-8993(00)03156-5. [56]MinnichV, Smith MB, Brauner MJ, Majerus PW. Glutathione biosynthesis in human erythrocytes. I. Identification of the enzymes of glutathione synthesis in hemolysates. J. Clin. Invest. 1971;50:507513.https://doi: 10.1172/JCI106519.

[57]Shcharbina N Yu. Effect of magnesium ions on lipid peroxidation and antioxidant system in cerebral ischemia. Proceed. Natl. Ac.Sci.Bel., Ser. Med.Sci. 2008; 3: 8590.https://doi:10.13140/2.1.4839.5206.

[58]Kostellow AB, Morrill GA. Ironcatalyzed lipid peroxidation in aortic cells in vitro: protective effect of extracellular magnesium. Atherosclerosis. 2004; 175:1522.https://doi.org/10.1016/j. 